\title{
Use of Bacterial Protein Powder in Commercial Fly Ash Pozzolana Cements for High Performance Construction Materials
}

\author{
Sudipta Majumdar ${ }^{1}$, Manas Sarkar ${ }^{1}$, Trinath Chowdhury ${ }^{1}$, \\ Brajadulal Chattopadhyay $^{{ }^{*}}$, Saroj Mandal ${ }^{2}$ \\ ${ }^{1}$ Department of Physics, Jadavpur University, Kolkata, India \\ ${ }^{2}$ Department of Civil Engineering, Jadavpur University, Kolkata, India \\ Email: "bdc_physics@yahoo.co.in
}

Received September 13, 2012; revised October 10, 2012; accepted October 27, 2012

\begin{abstract}
Concrete, widely used construction material suffers from cracks and low tensile strength that cut down the load capacity resulting in shortening of self-life. Biologically modified construction materials become more popular for higher strength and long-term sustainability. This investigation deals with the compressive and flexural strengths increment of a novel bacterial protein (bioremediase) incorporated pozzolana cement based mortar specimens. This protein also increases durability and crack repairing attributes that is more effective in pozzolana cement. Higher constituent percentage of silicate in pozzolana cement leads to higher silica leaching activity within the matrix manifesting of higher strength and durability of the samples. Eco-friendliness and wide range temperature stability lead added advantage to the protein for potential additive in high performance concrete technology. This means in practice that a substantial part of the cement of the mortar/concrete mixtures can be left out while still obtaining needed final strength. This would substantially improve the ecological footprint (sustainability) of mortar/concrete, as it is particularly cement that causes (during its production) massive $\mathrm{CO}_{2}$ emission what negatively affects the global climate (significantly contributes to global warming).
\end{abstract}

Keywords: Compressive Strength; Durability; Microbial Protein; Pozzolana Cement

\section{Introduction}

Concrete, the commonplace construction material allover the world is ascribed with high compressive strength but modest tensile strength [1]. Its inadequacy of tensile strength paves way for counterbalancing via the use of reinforcements (e.g. steel rebar). However, even after reinforcement, cracks appear over concrete structures, which is the fallout of applied structural loading, shrinkage and thermal deformations. These are in true sense, inevitable and expected within the context of practicality [2]. Commonly used reinforcement agents in construction materials corrode the structure internally and decrease the self-life of the structures. Occurrence of cracks cut down the load capacity and stiffness of the concrete structure by creating passage to ions-the chief culpable of concrete deterioration [3]. Chloride ions, oxygen and carbonating agents can diffuse through the cracks and end up in corroding reinforcing steel, which contributes to the extensive disintegration of concrete structure glob-

*Corresponding author. ally [4]. Hence occurrence of cracks is a prevalent form of damage in concrete structures. All these lead to appreciation of manufactural and maintenance cost of concrete based structure coupled with potential of environmental hazards. In this context, concept of microbiologically induced bio-concrete materials holds water.

Biomineralization is a metabolic process of formation of hard structures, surfaces or scales by combining minerals with organic compounds of some specific microorganisms [5]. According to Belkova [6], metabolic activity of some specific microorganisms plays a pivotal role in the transformation of many members of the periodic table. Specific microbial proteins influence the biomineralization process either through guiding prevention or formation of mineral deposits [7]. This biominerology concept has been looked into very keenly for development of new bioconcrete material $[8,9]$, cleaning of concrete surface [10] and imparting microorganisms directly for inducing calcite precipitation in concrete crack [11, 12].

In commercial purposes, the commonplace cement 
used is fly ash or slag based pozzolana cement, which is prepared by apposite mixing of Ordinary Portland cement (OPC) and any pozzolana material such as fly ash, blast furnace slag, brick powder, rice husk ash etc. Portland Pozzolana cement (PPC) is generally slow setting and exhibits sulphate resistance attribute [1]. Owing to salvage of waste products such as fly ash and slag pozzolana cement fill the bill of eco-friendly construction ingredient. The present study furnishes a performance analysis of the bacterium BKH1 and one of its secretary protein (bioremediase) regarding compressive strength enhancement, tensile strength and self-healing attributes of Portland Pozzolana cement based specimens. Comprising with the observations of Ordinary Portland cement based specimens obtained earlier; we are trying to affirm the practical applicability of the bioremediase protein in fly ash/slag based pozzolana cements as alternative approach to construction technology.

\section{Material and Methods}

\subsection{Bacterium and Its Growth Condition}

The bacterium was isolated from the crude soil samples of a hot spring at Bakreshwar, West Bengal, India. This is a facultative anaerobic and iron reducing bacterium and closely related with the Thermoanaerobactor fermicutes [13]. In sealed glass pressure vials it was cultured anaerobically (in presence of $\mathrm{CO}_{2}$ atmosphere) [14] in a synthetic growth medium (containing $\mathrm{Fe}(\mathrm{OH})_{3}-0.1$ $\mathrm{M}, \mathrm{Na}_{2} \mathrm{HPO}_{4}-0.6 \mathrm{~g} / \mathrm{L}, \mathrm{KCl}-0.33 \mathrm{~g} / \mathrm{L}, \mathrm{Na}_{2} \mathrm{CO}_{3}-2.5$ $\mathrm{g} / \mathrm{L}$, yeast extract $-0.02 \%$ and peptone-0.5\%) at $\mathrm{pH} 8.0$ and $65^{\circ} \mathrm{C}$ temperature [9]. This bacterium has been found to survive up to $\mathrm{pH} 12.0$ of the growth medium; however its growth rate is slowed down at this high $\mathrm{pH}$ level [13]. A few proteins are secreted by this anaerobic bacterium in the growth medium during its growth. One of the secretary proteins has shown silica-leaching property having molecular weight of $28 \mathrm{kDa}$ [13] similar to marine sponge [15]. The protein is named as "Bioremediase", which is non-harmful, eco-friendly and possessing additive characteristics.

\subsection{Purification of Bacterial Protein from Growth Medium}

About $100 \mathrm{ml}$ bacteria grown culture medium (6 - 8 days old with cell concentration of $10^{8}$ bacterial cells $/ \mathrm{ml}$ culture) was taken in a polypropylene tube and centrifuged. The cell free supernatant of the centrifuged culture medium was taken in a round bottom flask and lyophilized (Freeze dryer FD-1, Rikakikai, Toshiba) to dust powder (approximately $600 \mathrm{mg}$ powder obtained from $100 \mathrm{ml}$ bacterium grown cultured medium). The dust powder was then dissolved in $10 \mathrm{ml}$ deionized distilled water and
$20 \mathrm{ml}$ of ice-cold acetone was added to it and kept at $4^{\circ} \mathrm{C}$ for overnight. The crude proteins thus precipitated were separated by centrifugation and lyophilized to dust crude protein powder (about $200 \mathrm{mg}$ obtained from $600 \mathrm{mg}$ dust powder). The crude protein was then dissolved in 2 $\mathrm{ml}$ of deionized sterile water and loaded on Sephadex G-100 column $(100 \mathrm{~cm} \times 1 \mathrm{~cm})$. Fractions $(1 \mathrm{ml}$ each) were collected through fraction collector (Eyela DC1000). Measuring the optical densities of the fractions at $280 \mathrm{~nm}$ monitored the protein containing fractions. Biosilicifiation activity of each column-purified protein containing fractions was performed using tetraethoxyorthosilicate (TEOS) as substrate. Those fractions showed biosilicification activity were pooled, concentrated by lyophilization and similarly eluted through the same Sephadex G-100 column. Protein containing eluted fractions were then pooled and dialyzed. The powder bioremediase protein was obtained after lyophilization (80 mg approximately) and stored in screw capped plastic container at room temperature for further work.

\subsection{Preparations of Mortar Samples for Compressive Strength}

Mortar samples (6 samples for each category) were prepared by using commercially available fly ash pozzolana 43 grade cement [16]. If the 28 days curing strength attains between 33 - 43 Mega Pascal (MPa), the cement is called 43-grade cement as per Indian standard (IS). IS 650 standard sand [17] was used by mixing with cement (3:1 w/w) for mortar samples preparation. The sand was sieved by passing through $850 \mu \mathrm{M}$ IS Sieve and not more than $10 \%$ by mass passing $600 \mu \mathrm{M}$ IS Sieve. Cement to water ratio was kept fixed at 0.4 for all samples preparation. Standard mortar cubes of following dimension (70.6 $\mathrm{mm} \times 70.6 \mathrm{~mm} \times 70.6 \mathrm{~mm}$ ) were cast as described by Ghosh et al. [9] as follows:

Control mortar cubes-Cement and sand mixture only. Bacterial cells incorporated mortar cubes-Cement + sand + bacterial cells (at three different concentrations as $10^{4}, 10^{5}, 10^{6}$ cells $/ \mathrm{ml}$ of water used).

Bioremediase protein incorporated mortar cubesCement + sand + bioremediase protein powder $(1,2,3$ and $4 \mu \mathrm{g} / \mathrm{g}$ cement used).

In bacterial cells incorporated mortar samples, the live cells present in the bacterial culture were added directly by mixing with water at required concentration(s) to the cement sand mixture. The live bacteria can survive up to 6 - 7 days within the mortar matrices and leach the bioremediase protein that actually performed the activity. In protein incorporated mortar samples, the active bioremediase protein was added directly to the cement-sand mixture with required dose(s). No additional nutritional material, only excluding those present in the diluted cul- 
tures, was supplemented in the mortar cubes during casting. All the samples were cured under water as well as in open air after $24 \mathrm{~h}$ of casting. The compressive strengths of the mortar cubes were measured after $3,7,14,28,60$, 120 days of curing.

\subsection{Preparation of Mortar Samples for Crack Repairing Test}

Standard mortar cubes (6 samples for each category) by using cement-sand mixture only were prepared as described earlier. Small bars of standard dimensions (68 $\mathrm{mm} \times 5 \mathrm{~mm} \times 15 \mathrm{~mm}$ ) were impregnated on the top surface to create artificial fissures in the mortar samples. After $24 \mathrm{~h}$ of casting the small bars were taken out. The cracks formed in the mortar samples were cured in water for 7 days. After that, the artificial cracks were repaired either by normal cement-sand mixtures or by BKH1 cells $\left(10^{4}-10^{6}\right.$ cells/ml water used) incorporated cement-sand mixtures or by bioremediase protein $(1-4 \mu \mathrm{g} / \mathrm{g}$ cement) incorporated cement-sand mixtures. All the samples were cured under both water and air after $24 \mathrm{~h}$ of second casting. The compressive strengths of the mortar cubes were measured after $3,7,14,28,60,120$ days of curing.

\subsection{Preparation of Mortar Specific Beam for Flexural Strength Test}

Specific beams (3 beams for each category) were prepared by using normal cement (PPC)-sand mixture for control specimens and bioremediase protein (1, 2, 3 and $4 \mu \mathrm{g} / \mathrm{g}$ cement used) incorporated cement-sand mixtures for experimental specimens. The dimension of the standard beam was $200 \mathrm{~mm} \times 50 \mathrm{~mm} \times 50 \mathrm{~mm}$. The beams were cured for 28 days under water and their flexural strength were determined in 4-point condition.

\subsection{Preparation of Mortar Samples for Water Absorption Test}

Mortar samples (6 samples for each category) by using normal cement-sand mixture as well as bacterial cells/ bioremediase protein incorporated cement-sand mixture were prepared as previously described. After 28 days of water curing, the samples were removed, dried and their masses were recorded. Then the samples were immerged in a water tank for 30 minutes. After that, the samples were removed from the water and their masses were recorded immediately. The samples were again kept in water for 24 hours. Their masses were similarly recorded after 24 hours of water curing. From the difference in values of the masses the percentage of mass increment were determined, which would determine the amount of water entered within the samples.

\subsection{Preparation of Mortar Samples for Sulphate Resistance Test}

Mortar samples (6 samples for each category) for sulphate resistant test were similarly prepared by using normal cement-sand mixture as well as bacterial cells/ bioremediase protein incorporated with cement-sand mixture as stated earlier. After 1 day, the samples were removed from the cassettes and their masses were recorded. Then the samples were immerged in a tank containing $5 \%$ sulphate solution $\left(5 \% \mathrm{MgSO}_{4}, \mathrm{pH} 7.0\right)$. The samples were cured under sulphate solution for 120 days and after curing, the samples were removed from the tank, air-dried and their masses again determined. From the differences of final and initial mass, the percentage of mass increment was determined. This will determine the amount of sulphate solution entered within the samples.

\subsection{Biochemical Assay of Bioremediase Protein Using PPC and OPC Respectively as Substrate}

In each reaction, $50 \mathrm{mg}$ of cement was dispersed in 500 $\mathrm{ml}$ deionised distilled water. Tris-HCl buffer $(20 \mu \mathrm{l}$ of 20 $\mathrm{mM}, \mathrm{pH}$ 8.0) was added to the cement solution and the final volume was made to $1 \mathrm{ml}$ with deionised distilled water. Different concentrations of bioremediase protein ( $0-140 \mu \mathrm{g} / \mathrm{g}$ cement) were then added to the reaction mixtures and reaction was performed at $65^{\circ} \mathrm{C}$ for 180 minutes. The reaction mixtures were then centrifuged at $11,000 \times \mathrm{g}$ for 20 minutes. The supernatants thus obtained were separated carefully and to which $1 \mathrm{ml}$ of $1 \mathrm{M}$ $\mathrm{NaOH}$ was added to stop the reaction. The released silicic acid was determined by Molybdate assay [18]. Optical densities of reaction samples were measured at $405 \mathrm{~nm}$ against control sample (without protein).

Similar biochemical reaction was also set up by using different amount of cement (varied from $0-140 \mathrm{mg}$ ) with fixed bioremediase protein concentration $(50 \mu \mathrm{g} / \mathrm{g}$ cement). The amount of silica released was determined similarly.

\subsection{Statistical Analysis}

In every experiment, 6 samples were prepared for each category of testing. Each experiment was repeated twice. Data was thus presented an average $(\mathrm{N}=12)$ with \pm standard deviation (SD). The percentage increments of all data were calculated with respect to control value.

\section{Results and Discussion}

The purpose of this study was to observe the effect of the bacterial cells (BKH1) and its protein (bioremediase) on the mortar samples prepared by using fly ash based po- 
zolanna cements. The positive effects of bacterium BKH1 and its bioremediase protein have already been studied on mortar/concrete samples by using ordinary Portland cements (OPC). But OPC is not commercially available and in most cases, locally commercially available cements specially pozolanna cements are used for construction purposes.

\subsection{Effect of Bacteria on Compressive Strength}

Figure 1 vividly describes the development of compressive strength of mortar cubes prepared by varying concentrations of bacterial cells using Portland Pozzolanic cement. The samples were cured for different days at room temperature in air and their compressive strengths were measured. It was noted that compressive strength of the mortar cubes augmented with addition of the bacterial cells at every stages of curing compared to the control specimens (devoid of the bacterial cells). The utmost $40.6 \%$ increment in regard to control after 28 days of curing and $41.8 \%$ increment after 120 days of curing were observed due to incorporation of bacterial cells directly to the cement-sand mixtures. The maximum increment in compressive strength was attained at the bacterial concentration of $10^{5}$ cells per $\mathrm{ml}$ of water used in mortar preparation.

The observations of same stature were noted when the mortar samples were cured in water (Figure 2), where $39.4 \%$ increment in compressive strength was registered for 28 -days cured samples and $42.4 \%$ increase in case of 120-days cured samples impregnated with bacterial cells at a concentration of $10^{5}$ cells per ml of water used in mortar preparation. Concrete is one of the most heterogeneous materials. Mortar cubes were prepared manually. Manual compactness of the mortar samples sometimes vary and this may reflect in the strength measurement. But overall results showed consistency in the compressive strength increment.

\subsection{Effect of Bioremediase Protein on Compressive Strength}

Sephadex G-100 column- purified pure bacterial bioremediase protein -admixed mortar samples when cured at room temperature in the air, displayed sharp increment of compressive strength at all ages (3, 7, 14, 28 and 120 days curing ages respectively) in match against normal control samples (Figure 3). Maximum compressive strength was attained at the purified protein concentration of $3 \mu \mathrm{g}$ per g of cement used ( $45 \%$ and $47.4 \%$ higher in magnitude compared to control in case of 28 days and 120 days of air curing respectively.

Similar trend of results were obtained when compressive strength of pure protein-admixed water cured mortar samples were noted (Figure 4).

\subsection{Crack Repairing Activity of BKH1 Cells}

To figure out the feasibility of the bacterial protein in practical repairing circumstances, the artificially crack healing study by this novel biomaterial requires special attention. In Figures 5 and 6, compressive strength of mortar cubes where artificially generated cracks were repaired by normal cement-sand paste and of those cubes where the repairing material was bacterial cells (of different cell concentrations) admixed cement-sand paste respectively were furnished.

It clearly displayed bacterial cell of $10^{5}$ cells per ml concentration having an extra edge in terms of crack repairing efficacy $(40.6 \%$ strength increment in 28-days air-cured samples and 38.9\% strength increment for 28

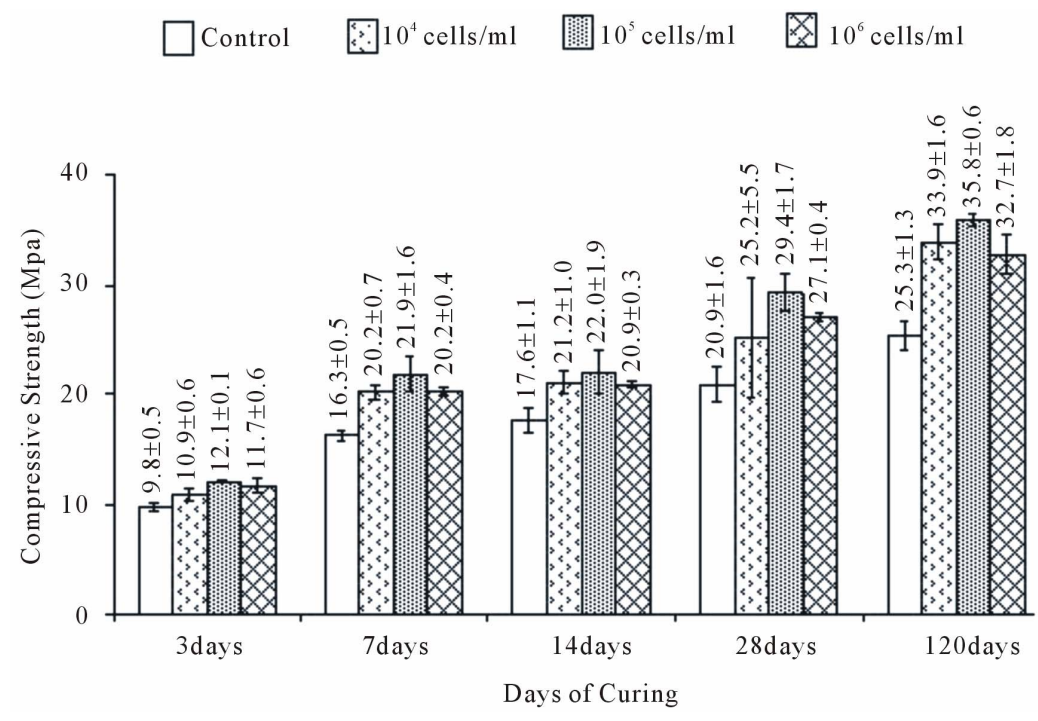

Figure 1. Mortar compressive strength with BKH1 cell under air curing. 


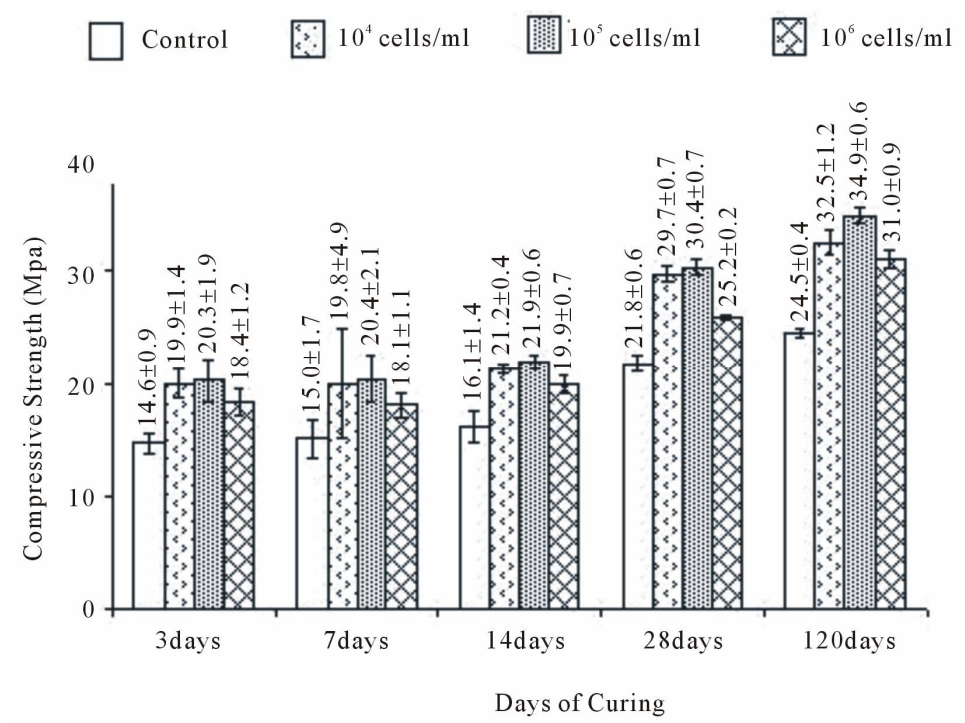

Figure 2. Mortar compressive strength with BKH1 cell under water curing.

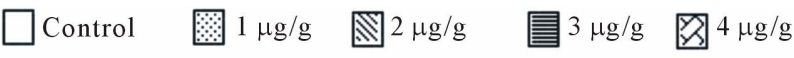

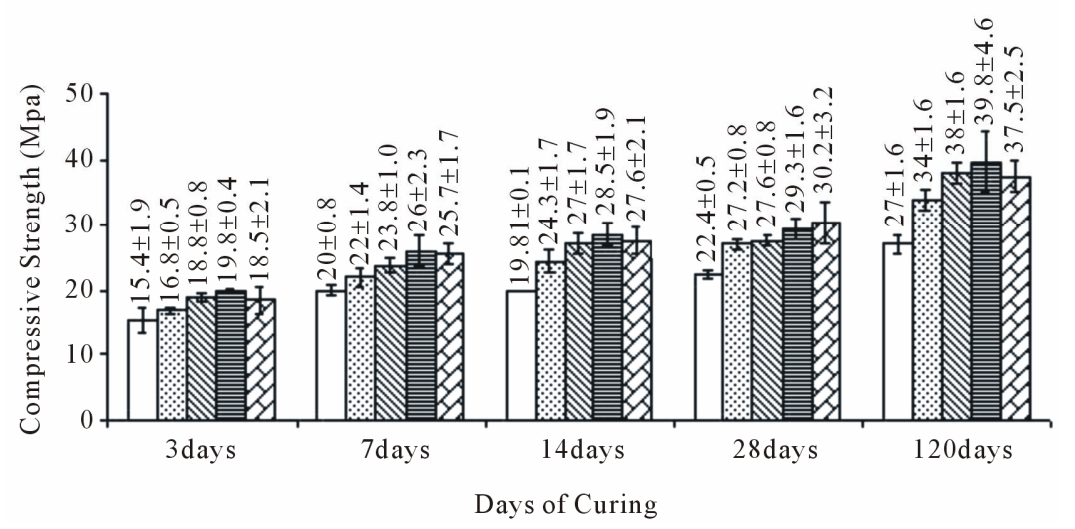

Figure 3. Mortar compressive strength with bioremediase protein under air curing.

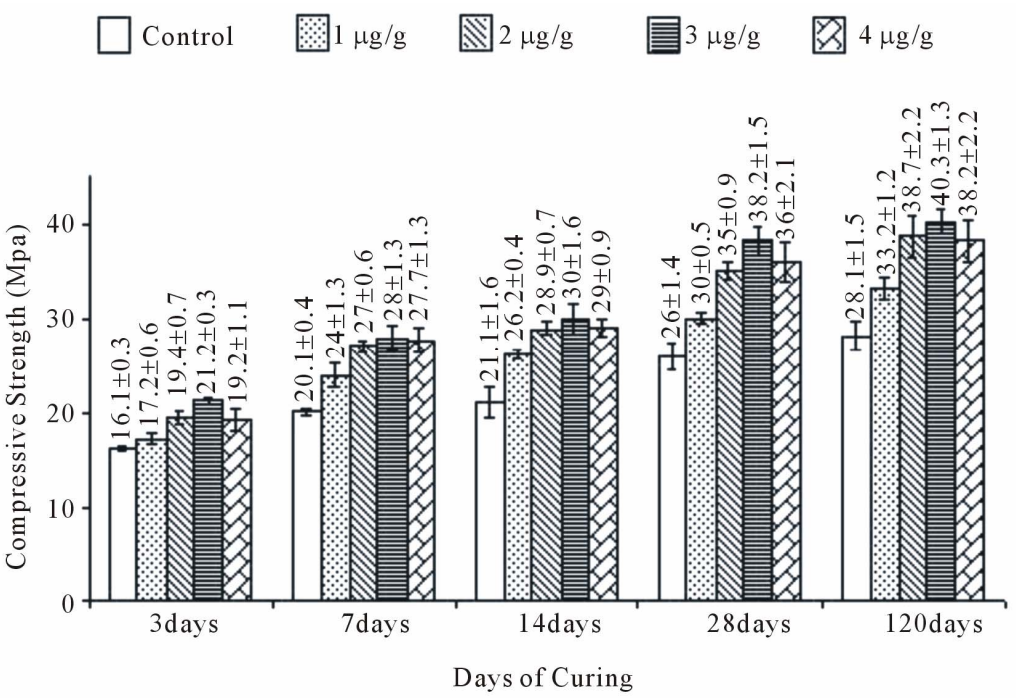

Figure 4. Mortar compressive strength with bioremediase protein under water curing. 


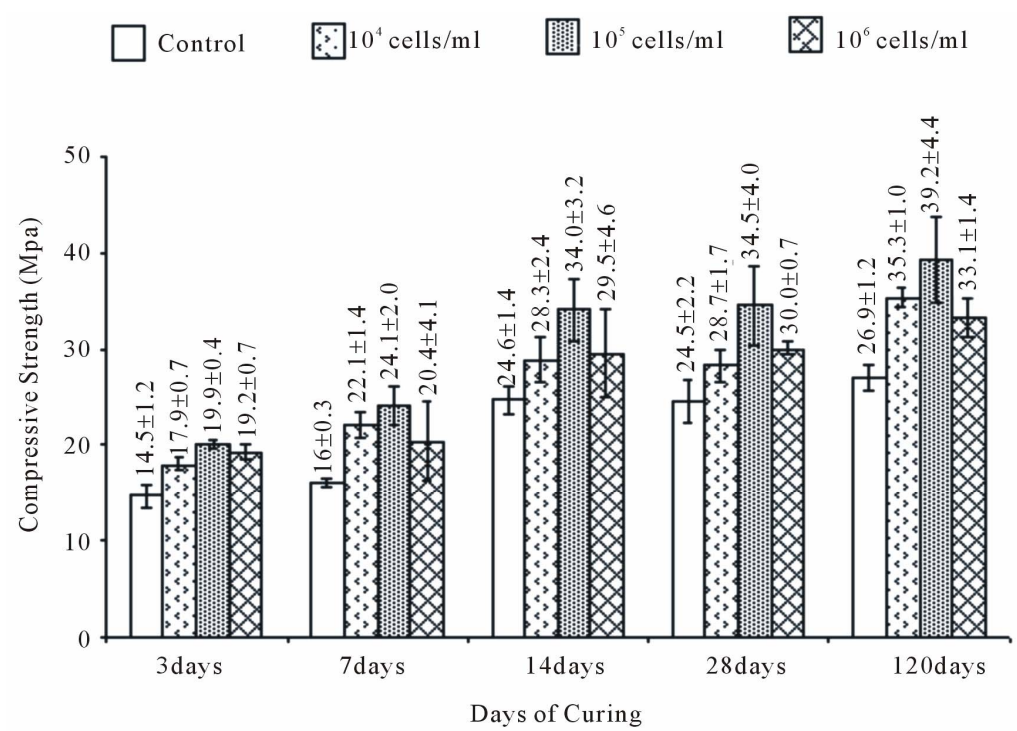

Figure 5. Compressive strength of the mortar whose crack was repaired by BKH1 cell incorporated cement-sand mixture (air curing).

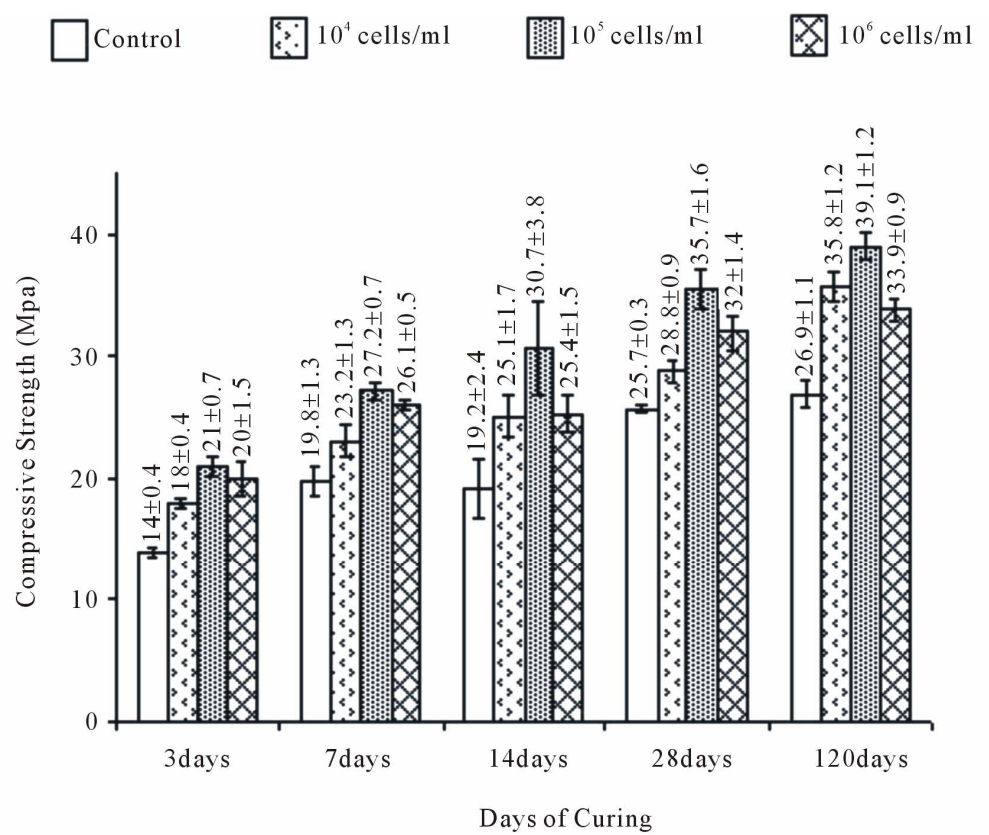

Figure 6. Compressive strength of the mortar whose crack was repaired by BKH1 cell incorporated cement-sand mixture (water curing).

days water-cured samples). This crack-repairing efficacy was further increased with increasing days of curing (45.5\% for air curing and $45.3 \%$ for water curing respectively when incorporated with bacterial cells at $10^{5}$ cells/ml).

\subsection{Crack Repairing Activity of Bioremediase Protein}

Bioremediase protein amended cement-sand paste was found to be similarly competent compared to normal cement-sand paste in context of crack-repairing ability. It was observed that the purified protein in concentration of $3 \mu \mathrm{g} / \mathrm{g}$ of cement used displayed highest potency (compressive strength augmentation $43.8 \%$ for air curing and $46.8 \%$ respectively for 28-days air-cured and water-cured samples) (Figures 7 and 8 ).

\subsection{Effect of Bioremediase Protein on Flexural Strength}

Flexural strength of specific mortar beam has been ana- 


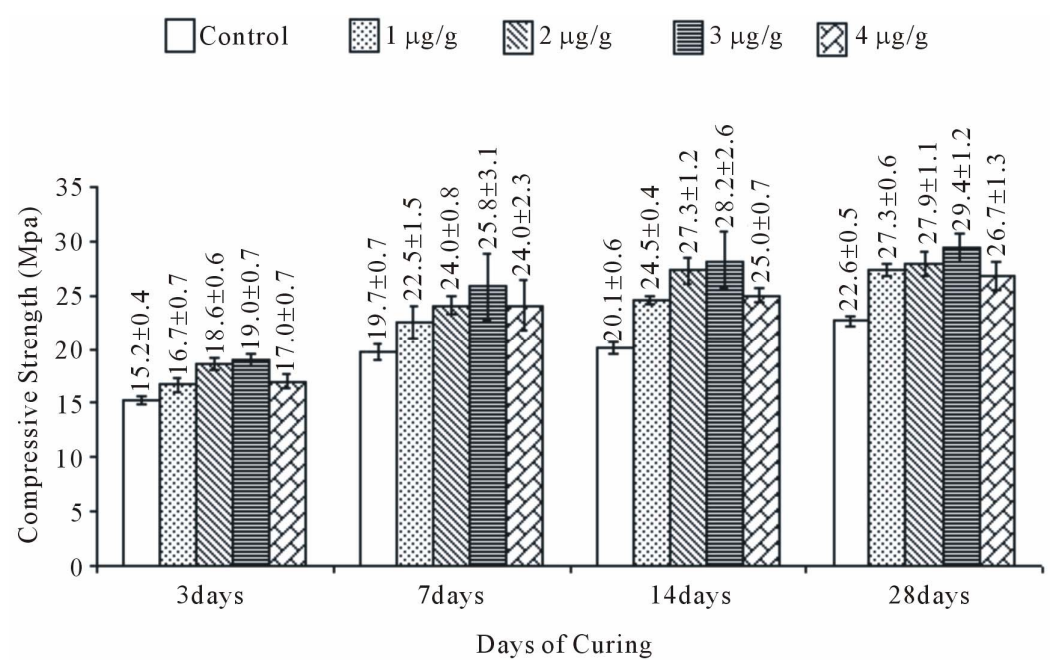

Figure 7. Compressive strength of the mortar whose crack was repaired by bioremediase protein incorporated cement-sand mixture (air curing).

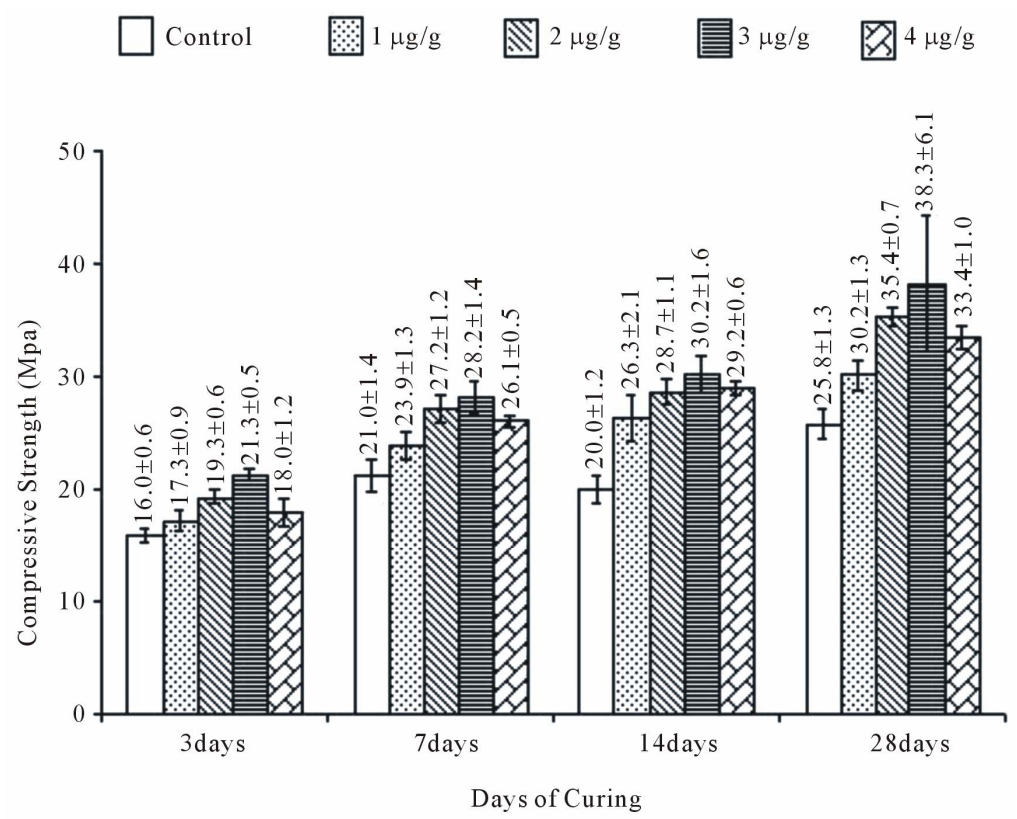

Figure 8. Compressive strength of the mortar whose crack was repaired by bioremediase protein incorporated cement-sand mixture (water curing).

lyzed by using bioremediase protein incorporated cement-sand mixture to the beams. Different concentration of protein was used in preparation of different beams. The flexural strength of bioremediase protein incorporated mortar beams was found higher compared to control beam. The maximum flexural strength increment was $33 \%$ with $3 \mu \mathrm{g} / \mathrm{g}$ bioremediase protein incorporated samples (Figure 9).

\subsection{Effect of Bacterial Cells and Bioremediase Protein on Water Absorption}

Durability analysis of BKH1 cells or its bioremediase protein on cement mortar specimens is very crucial for sustainable construction purposes. It was noted that mass of mortar samples impregnated with bacteria and also with the bioremediase protein were less altered as compared to the control samples. An average increase of only $2.2 \%$ and $4.7 \%$ in mass were noted for mortar samples impregnated with bacterial cells concentration of $10^{5}$ cells per $\mathrm{ml}$ after $30 \mathrm{~min}$ and $72 \mathrm{~h}$ respectively (Table 1).

Whereas the bioremediase protein incorporated mortar samples showed less increase in mass (only $1.7 \%$ and $3.7 \%$ after $30 \mathrm{~min}$ and $72 \mathrm{~h}$ respectively when protein was used at $3 \mu \mathrm{g} / \mathrm{g}$ cement) due to water absorption (Table 2). 


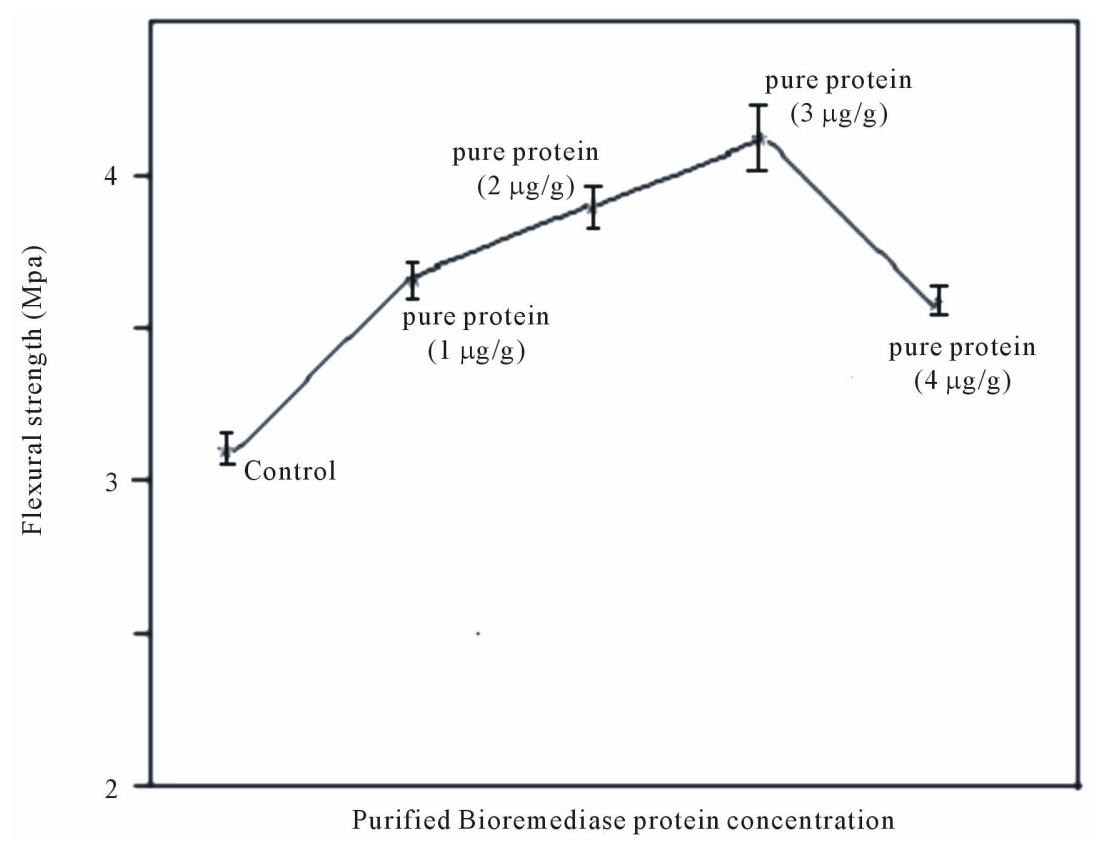

Figure 9. Flexural strength of mortar bar.

Table 1. Water absorption (28 days) using BKH1 cells.

\begin{tabular}{cccccc}
\hline Mortar Samples & Initial mass (g) & Mass after $30 \mathrm{~min}(\mathrm{~g})$ & \% Increment in mass & Mass after $72 \mathrm{~h}(\mathrm{~g})$ & \% Increment in mass \\
\hline Control & $735.5 \pm 0.4$ & $756.8 \pm 0.4$ & 2.9 & $790.5 \pm 0.6$ & 7.5 \\
$10^{4}$ cells/ml water used & $730.5 \pm 0.3$ & $747.0 \pm 0.2$ & 2.3 & $772.0 \pm 0.4$ & 5.7 \\
$10^{5}$ cells/ml water used & $733.2 \pm 0.5$ & $749.2 \pm 0.5$ & 2.2 & $767.6 \pm 0.4$ & 4.7 \\
$10^{6}$ cells/ml water used & $720.0 \pm 0.4$ & $736.9 \pm 0.3$ & 2.3 & $765.2 \pm 1.0$ & 6.24 \\
\hline
\end{tabular}

Data are presented mean $\pm \mathrm{SD} ; \mathrm{N}=12$.

Table 2. Water absorption (28 days) using bioremediase protein.

\begin{tabular}{cccccc}
\hline Mortar Samples & Initial mass (g) & Mass after 30 min (g) & \% Increment in mass & Mass after 72 h (g) & \% Incrementin mass \\
\hline Control & $735.7 \pm 0.5$ & $754.8 \pm 0.4$ & 2.6 & $789.7 \pm 0.4$ & 7.3 \\
$1 \mu \mathrm{g} / \mathrm{g}$ cement & $733.9 \pm 0.5$ & $750.2 \pm 0.5$ & 2.2 & $781.3 \pm 0.7$ & 6.5 \\
$2 \mu \mathrm{g} / \mathrm{g}$ cement & $730.7 \pm 0.2$ & $747.4 \pm 0.2$ & 2.3 & $769.4 \pm 0.1$ & 7.3 \\
$3 \mu \mathrm{g} / \mathrm{g}$ cement & $725.5 \pm 0.3$ & $737.7 \pm 0.2$ & 1.7 & $752.6 \pm 0.2$ & 3.7 \\
$4 \mu \mathrm{g} / \mathrm{g}$ cement & $728.5 \pm 0.3$ & $744.5 \pm 0.4$ & 2.2 & $765.6 \pm 0.2$ & 5.1 \\
\hline
\end{tabular}

Data are presented mean $\pm \mathrm{SD} ; \mathrm{N}=12$.

\subsection{Effect of Bacterial Cells and Bioremediase Protein on Sulphate Resistance}

The results of sulphate resistance tests distinctly asserted the positive influence of these biomaterials on cement mortar specimens. It was noted that mass of mortar samples impregnated with bacteria and also with the bioremediase protein were less affected as compared to the control samples. An increase of only $4.5 \%$ in mass was noted for samples impregnated with bacterial concentration of $10^{5}$ cells per ml (Table 3 ).
Similarly $4.6 \%$ of mass increment was seen in bioremediase protein admixed mortar samples with protein concentration of $3 \mu \mathrm{g} / \mathrm{g}$ of cement used (Table 4). It is thus evident from these data that bacterium/bioremediase protein incorporated biomaterials are less prone to sulphate attack compared to normal cement-sand mortar.

Water absorption test and sulphate resistant test both thus confirm that bacterium BKH1 or its bioremediase protein amended biomaterials are more durable compared to normal mortar. 


\subsection{Viability of the Bioremediase over Long Periopd and Wide Temperature Range}

Preserving them at two extreme conditions the activity of the protein remained almost unaffected. In performing these experiments, bioremediase protein powder was stored at $65^{\circ} \mathrm{C}$ and $-20^{\circ} \mathrm{C}$ temperature respectively for 6 months. The protein was then used in preparation of mortar sample as stated earlier. The compressive strength of the stored bioremediase protein impregnated mortar samples was found to increase in similar fashion as observed in fresh protein samples earlier (Table 5). More than $40 \%$ strength improvement was noticed against the stored protein impregnated mortar samples. This result suggests that the bioremediase protein can be stored and used for practical construction purposes without having any sophisticated storage facility.

\subsection{Bio-Silicification Assay of Bioremediase Using OPC and PPC}

Biochemical assay for bioremediase protein using ordinary Portland cement and pozolanna Portland cement respectively as substrate clearly indicated the activity of the protein was more in PPC than OPC in all-experimental conditions (Figures 10 and 11).

This is in agreement with the results obtained in PPC based mortar samples. The chemical composition of pozzolanas varies considerably. Of the active oxides,

Table 3. Sulphate resistant test with BKH1 cells incorporated mortar samples.

\begin{tabular}{cccc}
\hline Mortar & Initial mass & Final mass & \% Increment \\
\hline Samples & $(\mathrm{g})$ & $(\mathrm{g})$ & $(\mathrm{g})$ \\
Control & $735.0 \pm 0.5$ & $796.4 \pm 0.6$ & 8.5 \\
$10^{4}$ cells/ml water used & $731.6 \pm 0.4$ & $783.4 \pm 0.5$ & 7.1 \\
$10^{5}$ cells/ml water used & $737.5 \pm 0.4$ & $770.5 \pm 0.5$ & 4.5 \\
$10^{6}$ cells/ml water used & $734.2 \pm 0.5$ & $789.2 \pm 0.5$ & 7.5 \\
\hline
\end{tabular}

Data are presented mean $\pm \mathrm{SD} ; \mathrm{N}=12$.

Table 4. Sulphate resistant test with bioremediase protein incorporated mortar samples.

\begin{tabular}{cccc}
\hline Mortar samples & Initial mass (g) & Final mass (g) & \% Increment (g) \\
\hline Control & $738.2 \pm 0.3$ & $799.5 \pm 0.4$ & 8.2 \\
$1 \mu \mathrm{g} / \mathrm{g}$ cement & $736.1 \pm 0.2$ & $790.1 \pm 0.3$ & 6.9 \\
$2 \mu \mathrm{g} / \mathrm{g}$ cement & $735.2 \pm 0.5$ & $785.0 \pm 0.5$ & 6.5 \\
$3 \mu \mathrm{g} / \mathrm{g}$ cement & $737.8 \pm 0.4$ & $771.2 \pm 0.4$ & 4.6 \\
$4 \mu \mathrm{g} / \mathrm{g}$ cement & $730.6 \pm 0.2$ & $771.1 \pm 0.3$ & 5.5 \\
\hline
\end{tabular}

Data are presented mean $\pm \mathrm{SD} ; \mathrm{N}=12$.
Table 5. Effect on compressive strength by bioremediase protein stored at two extreme conditions for 6 months.

\begin{tabular}{ccc}
\hline Sample specification & \multicolumn{2}{c}{ Compressive strength (MPa) } \\
\hline & $\begin{array}{c}\text { Protein stored } \\
\text { at } 65^{\circ} \mathrm{C}\end{array}$ & $\begin{array}{c}\text { Protein stored } \\
\text { at }-20^{\circ} \mathrm{C}\end{array}$ \\
\hline Control mortar & $25.8 \pm 1.1$ & $25.2 \pm 1.2$ \\
$\begin{array}{c}\text { Mortar with protein } \\
(1 \mu \mathrm{g} / \mathrm{g} \text { cement })\end{array}$ & $30.7 \pm 1.4(18.6)$ & $30.2 \pm 1.8(19.7)$ \\
$\begin{array}{c}\text { Mortar with protein } \\
(2 \mu \mathrm{g} / \mathrm{g} \text { cement })\end{array}$ & $37.1 \pm 1.3(43.8)$ & $36.6 \pm 1.5(41.2)$ \\
$\begin{array}{c}\text { Mortar with protein } \\
(3 \mu \mathrm{g} / \mathrm{g} \text { cement })\end{array}$ & $37.7 \pm 1.3(46.1)$ & $36.2 \pm 1.4$ (43.6) \\
$\begin{array}{c}\text { Mortar with protein } \\
(4 \mu \mathrm{g} / \mathrm{g} \text { cement })\end{array}$ & $36.2 \pm 2.1(40.3)$ & $34.3 \pm 1.8(36.2)$ \\
\hline
\end{tabular}

Data are presented mean $\pm \mathrm{SD} ; \mathrm{N}=12$. The value within parenthesis indicates the \% increment with respect to control.

silica is normally considered to be the most important in the form of silicate and should not normally fall below $40 \%$ of the total; indeed some of the best pozzolanas have silica contents above $90 \%$ [1]. On the other hands, in ordinary portland cements, silica contents vary from $19 \%$ - 23\% only. Bioremediase protein can leach silica from silicate compounds and help to form calcium-aluminium-silicate by using the available silica within the concrete/mortar matrices [12].

\subsection{Comparative Analysis of the Effect of BKH1 on OPC and PPC}

Previously it was observed that only $25 \%$ to $30 \%$ strength increment was achieved by using ordinary Portland cement with BKH1 cells or its specific bioremediase protein incorporated mortar samples $[9,16]$. This study showed $40 \%$ - $45 \%$ strength increment of PPC with the same bacterium or its bioremediase protein. The higher content of silicate in PPC helps to increase the activity of bioremediase enzyme. This clearly explained the higher strength improvement in pozzolanas cements when BKH1 cells or its specific protein (bioremediase) was used (Table 6). The increment of crack repairing capacity of bioremediase protein was also more significant in PPC than that in OPC (Table 6). The ultrasonic pulse velocity was also more increased that revealed more compactness of protein amended PPC mortar samples than OPC mortar samples. Sulphate resistance and water absorption tests confirmed that those two properties were more or less similarly increased.

\section{Conclusion}

Bioremediase protein secreted by the bacterium BKH1 is a potential additive agent for different types of cements. 


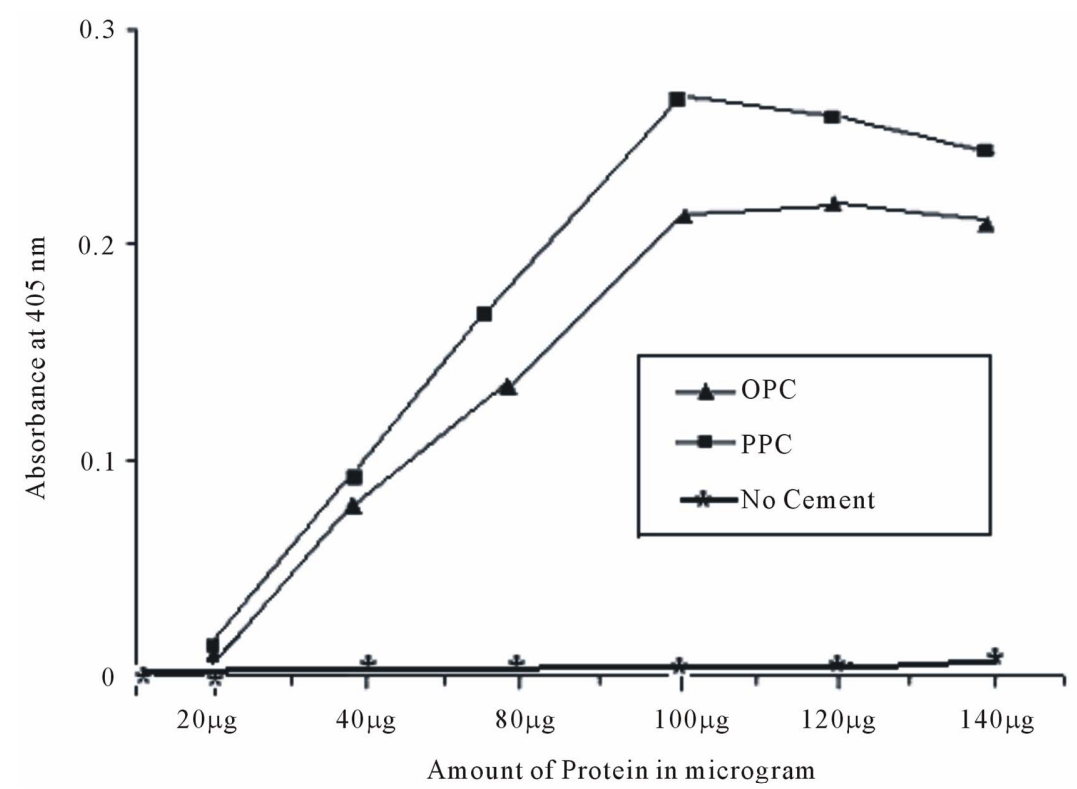

Figure 10. Bio-silicificaton assay of bioremediase protein using cement $(50 \mathrm{mg})$ as substrate.

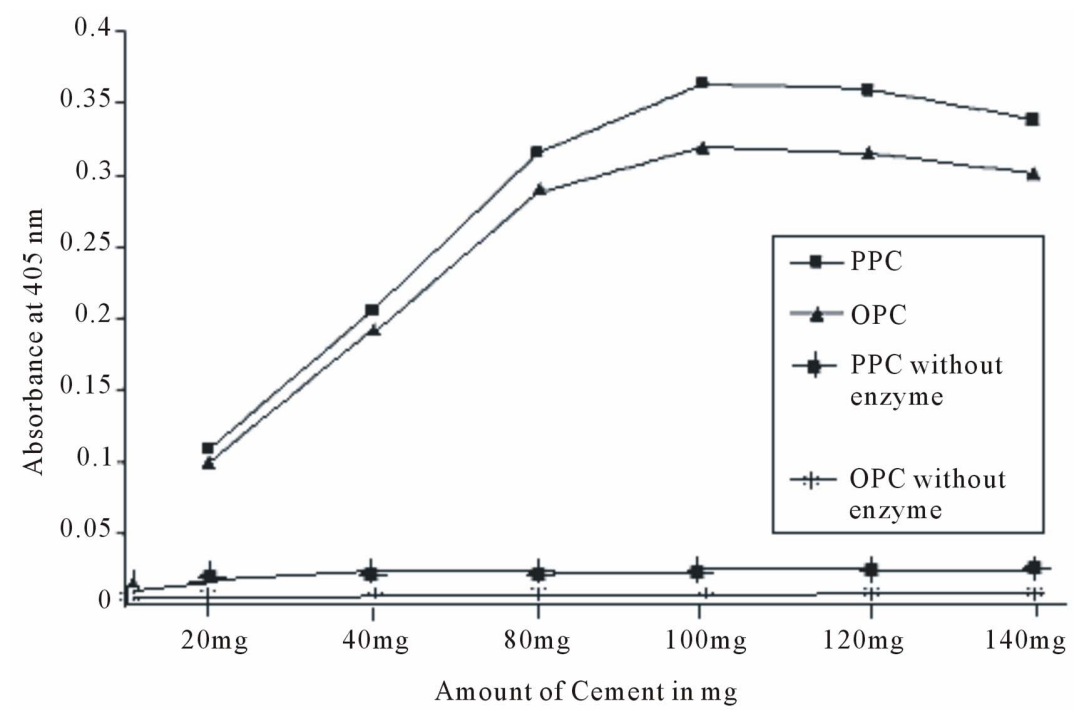

Figure 11. Bio-silicificaton assay of bioremediase protein $(100 \mu \mathrm{g})$ using different concentrations of cement as substrate.

Table 6. Comparative performance analysis using BKH1 cells on two different cements.

\begin{tabular}{ccccccc}
\hline & & & \% Increment of & & \\
\hline & Compressive & Crack-healing & Ultrasonic & Mass in water & Mass in \\
Cement & Strength of & Property of & Pulse velocity & & Absorption & Sulphate \\
Type & $(28 \mathrm{~d}$ cure $)$ & $(28 \mathrm{~d}$ cure $)$ & $(28 \mathrm{~d}$ cure $)$ & 30 min & $72 \mathrm{~h}$ & Absorption \\
OPC & 24.7 & 14.2 & 4 & 1.7 & 6.4 & 4.8 \\
PPC & 45 & 50.8 & 14 & 2.2 & 4.7 & 4.5 \\
\hline
\end{tabular}

The increment of strengths and other essential features of mortar/concrete materials are substantially higher for pozzolana cement based mortar/concrete materials than ordinary Portland cement based specimens when admixed to bioremediase protein. Opulence of silicate in fly ash pozzolana cements is behind the enhanced activity of 
the bioremediase protein that ushers a new hope in future construction technology. This means in practice that a substantial part of the cement of the mortar/concrete mixtures can be left out while still obtaining needed final strength. This would substantially improve the ecological footprint (sustainability) of mortar/concrete, as it is particularly cement that causes (during its production) massive $\mathrm{CO}_{2}$ emission what negatively affects the global climate.

\section{Acknowledgements}

The financial assistance to this experimental study received from Department of Biotechnology (DBT), Government of India, New Delhi (R\&D grant and File No. BT/PR-11289/BCE/08/707/2008, Dated 30.05.2011) and Intellectual Ventures Asia Pvt. Ltd. with PROGRAM ADDENDUM (EXPAND) (Program Addendum No. B-12881) are gratefully acknowledged. Fellowship assistance for Sudipta Majumdar from DST-PURSE Programme, Jadavpur University is also gratefully acknowledged.

\section{REFERENCES}

[1] P. K. Mehta, "Advancement in Concrete Technology," Journal of Concrete International, Vol. 96, 1999, pp. 69-75.

[2] H. M. Jonkers, "Self-Healing Concrete: A Biological Approach,” In: S. Van der Zwaag, Ed., Self-Healing Materials: An Alternative Approach to 20 Centuries of Material Science, Springer, Inc., The Netherlands, 2007, pp. 195-204.

[3] S. K. Ramachandran, V. Ramkrishnan and S. S. Bang, "Remediation of Concrete Using Microorganisms," ACI Material Journal, Vol. 98, No. 1, 2001, pp. 3-9.

[4] M. A. T. M. Broekmans, "Deleterious Reactions of Aggregate with Alkalis in Concrete," Review of Mineralogy and Geochemistry, Vol. 74, No. 1, 2012, pp. 279-364. doi:10.2138/rmg.2012.74.7

[5] W. C. H. Skinner and H. A. Jahren, "Biomineralization," In: W. H. Schlesinger, Ed., Treatise on Geochemistry, Elsevier, 2003, pp. 117-184.

[6] L. N. Belkova, "Biomineralization in Natural Environments: The Effect of Microorganisms Inhabiting Hot Spring Water and Biomats on Mineral Formation," Geophysics Research Abstract, No. 7, 2005.

[7] A. L. Boskey, "Biomineralization: An Overview," Connective Tissue Research, Vol. 44, No. 1, 2003, pp. 5-9. doi:10.1080/03008200390152007
[8] P. Ghosh, S. Mandal, B. D. Chattopadhyay and S. Pal, "Use of Microorganisms to Improve the Strength of Cement-Mortar," Cement and Concrete Research, Vol. 35, No. 10, 2005, pp. 1980-1983. doi:10.1016/j.cemconres.2005.03.005

[9] S. Ghosh, M. Biswas, B. D. Chattopadhyay and S. Mandal, "Microbial Activity on Microstructure of Bacteria Modified Mortar," Cement and Concrete Composites, Vol. 31, No. 2, 2009, pp. 93-98. doi:10.1016/j.cemconcomp.2009.01.001

[10] B. De Graef, W. De Windt, J. Dick, W. Verstraete and N. De Belie, "Cleaning of Concrete Fouled by Lichens with the Aid of Thiobacilli,” Material Structure, Vol. 38, No. 284, 2005, pp. 875-882. doi:10.1007/BF02482254

[11] S. S. Bang, J. K. Galinat and V. Ramakrishnan, "Calcite Precipitation Induced by Polyurethane-Immobilized $\mathrm{Ba}$ cillus pasteurii,” Enzyme and Microbial Technology, Vol. 28, No. 4-5, 2001, pp. 404-409. doi:10.1016/S0141-0229(00)00348-3

[12] C. Rodriguez-Navarro, M. Rodriguez-Gallego, K. Ben Chekroun and M. T. Gonsalez-Munoz, "Conservation of Ornamental Stone by Myxococcus xanthus-Induced Carbonate Biomineralization,” Applied and Environmental Microbiology, Vol. 69, No. 4, 2003, pp. 2182-2193. doi:10.1128/AEM.69.4.2182-2193.2003

[13] M. Biswas, S. Majumdar, T. Chowdhury, B. D. Chattopadhyay, S. Mandal, U. Halder and S. Yamashaki, "Bioremediase a Unique Protein from a Novel Bacterium BKH1, Ushering a New Hope in Concrete Technology," Enzyme and Microbial Technology, Vol. 46, No. 7, 2010, pp. 581-587. doi:10.1016/j.enzmictec.2010.03.005

[14] B. D. Chattopadhyay, A. R. Thakur, R. K. Poddar and D. Dasgupta, "Effect of Calcium Ion on Methanosarcine barkeri MS,” Indian Journal of Experimantal Biology, Vol. 31, 1993, pp. 738-742.

[15] J. N. Cha, K. Shimizu, Y. Zhou, S. C. Christianssen, B. F. Chmelka, G. D. Stucky and D. E. Morse, "Silicatein Filaments and Subunits from a Marine Sponge Direct the Polymerization of Silica and Silicones in Vitro," Proceedings of National Academy of Sciences, Vol. 96, No. 2, 1999, pp. 361-365. doi:10.1073/pnas.96.2.361

[16] Bureau of Indian Standard, "IS 8112: Specification for 43-Grade Ordinary Portland Cement,” New Delhi, India, 1989.

[17] Bureau of Indian Standard, "IS 650: Specification for Standard Sand from Natural Sources of Ennor, Tamilnadu District, India for Concrete,” New Delhi, India, 1991.

[18] H. A. Douglas, M. D. Daniel, E. M. Daniel and A. A. Ilha, "Non-Peptide, Silicatein Alpha Inspired Silica Condensation Catalyst," Polymer and Material Science Engineering, Vol. 90, 2004, pp. 239-241. 